\begin{tabular}{lcr}
\hline & ANNALES \\
& UNIVERSITATIS MARIAE CURIE-SKLODOWSKA & \\
LUBLIN - POLONIA & \\
VOL. VI & SECTIO M & 2021 \\
\hline
\end{tabular}

\author{
Tomasz Wicha \\ Maria Curie-Skłodowska University in Lublin, Poland \\ tomasz.wicha@interia.pl \\ ORCID: https://orcid.org/0000-0003-3547-2238
}

\title{
The imposition of the state of emergency on the part of Poland in 2021 due to the border migration crisis with Belarus
}

\section{The introductory remarks}

The problem of the imposition of the state of emergency on the part of Poland in 2021 due to the border migration crisis with Belarus was the key issue in 2021 for the comprehensive analysis of the internal political conflict in Poland. The aspects that are going to be analysed in the article may reveal whether - in times of objective danger at the state border - the level of the political conflict remains stable. If the introduction of the state of emergency is not perceived as an issue that ought to limit the level of the political conflict on the political market of Poland, such a situation may demonstrate that the high amplitude of the disputes on the political arena of Poland is constant and cannot be reduced no matter the reason. This hypothesis will be tested by the analysis of the decision-making process and with the use of system analysis.

\section{The migration crisis in Europe in 2015}

The process of massive migration in Europe that had its peak in 2015 displayed the differences between the member states of the European Union. The states which were affected by the crisis located in the South of the EU had 
a completely different approach towards the issue than the states of the Central and Eastern Europe, which caused lack of solidarity and unity among European Union members ${ }^{1}$. The problem of the European migration crisis was dynamic and influenced the break of the attitude of the EU member states - Central and Eastern Europe states did not wish to agree for the quota system in which the number of immigrants would be dislocated for every EU states. Indeed, some of the EU states simply prioritised their national interest over the interest of the whole European Union. The crisis situation from 2015 therefore shook the organization to its core ${ }^{2}$. Moreover, the crisis displayed the lack of common foreign and immigration policies of the $\mathrm{EU}^{3}$. The unprecedented flows of immigrants who were approaching Europe confronted the EU with a variety of challenges ${ }^{4}$. Furthermore, the influx of immigrants exposed the weakness of the European asylum system ${ }^{5}$.

\section{The Polish approach towards the migration crisis in the European Union (2015)}

The attitude of the authorities of Poland concerning the immigration policy evolved with time ${ }^{6}$. The approach of Poland concerning the migration crisis which affected the European Union since 2011, changed in 2015 with the alteration of power in Poland after the parliamentary elections organised in the autumn of 2015. The attitude of the Civic Platform (PO) and Law and Justice party (PiS) towards the quota system was one of the main differences between two parties in which one party wanted to keep power (PO) and the latter (PiS) wanted to gain power after the parliamentary elections in $2015^{7}$. The Civic

1 A. Chojan, P. Olszewski, Kryzys migracyjny jako problem globalny. Konsekwencje dla polityki zagranicznej i bezpieczeństwa Unii Europejskiej, "Roczniki Nauk Społecznych”, 2018, vol. 10 (46), nr 1, p. 93-105.

2 M. Pacek, Polish migration Policy in the context of the migration crisis, "Studia Europejskie", 2020, nr 2, p. 85.

3 M. Dahl, A. Dziudziuk, Państwa Unii Europejskiej wobec kryzysu imigracyjnego z 2015 roku, "Unia Europejska”, 2017 (244), nr 3, p. 17.

4 A. Piłat, D. Potkońska, Local responses to the refugee crisis in Poland. Reception and integration, Warsaw 2017, p. 4.

5 J. Szymańska, Strategia Unii Europejskiej wobec kryzysu migracyjnego: priorytety, bariery, efekty, "Studia Biura Analiz Sejmowych", 201, nr 3 (51), p. 181.

6 L. Rajca, The evolution of the approach to the integration of immigrants in Poland, "Studia Europejskie", 2021, vol. 3, p. 83-94.

Compare: M. Lasoń, Stanowisko polskich partii politycznych wobec problemu uchodźstwa i imigracji w drugiej dekadzie XXI wieku, [in:] Migracja i uchodźstwo wyzwaniem dla bezpieczeństwa $i$ wspótpracy międzynarodowej w XXI wieku, ed. B. Molo, Kraków 2016, p. 89-102. 
Platform was ready to agree to the quota system in which a number of those who entered the territory of the European Union illegally would be relocated within every EU member state, Law and Justice fundamentally disagreed to such a course of action and classified the quota system as an action against the Constitution of the Republic of Poland because the will of the nation was not taken into consideration ${ }^{8}$. The government formed by the Civic Platform referred to the principle of the necessity for the EU solidarity and at the beginning agreed to accept the number of 2000 asylum seekers. After the shift of power as a result of the parliamentary elections in October, 2015, Poland did not accept the relocation scheme, as Law and Justice party was strongly against the dislocation of immigrants and was not eager to agree even for a one asylum-seeker being relocated to Poland via the quota system?

The migration crisis was the issue of a harsh debate on the European political arena, especially in the right wing parties in the V4 states ${ }^{10}$. The recommendation to establish a quota system as a tool to solve the problem was not perceived as a reasonable way to solve it. The social understanding of the migration problem and the attitude of the societies of the member states of the EU influenced the skeptical approach of the politicians of some of the EU states towards the migration crisis ${ }^{11}$. Furthermore, the social perception of the migration crisis turned from a neutral one into a strongly negative one ${ }^{12}$. There was a growing trend in the public debate of some of the EU states, e.g. in the Republic of Poland, to treat the influx of immigrants as a danger for to national security ${ }^{13}$.

8 The website of the portal YouTube, http://www.youtube.com, "Wystąpienie Jarosława Kaczyńskiego w Sejmie Rzeczypospolitej Polskiej dnia 16 września 2015 r., access 12.12.2021.

9 M. Zdanowicz, Poland's stance on the refugee and migration crisis in the European Union, "Białostockie Studia Prawnicze", 2021, vol. 26, nr 1, p. 100-101; M. Dahl, Europejski kryzys imigracyjny $z 2015$ roku i jego wptyw na prowadzona przez Polskę w latach 2015-2018 polityke zagraniczna, "Myśl Ekonomiczna i Polityczna”, 2019, nr 2 (65), p. 208-219.

10 A. Starzyk, Kryzys migracyjny a sytuacja partii prawicowych w Grupie Wyszehradzkiej w 2015 roku, "Wrocławskie Studia Politologiczne", 2016, nr 20, p. 109-123.

11 N. Adamczyk, Czy przyjmować uchodźców? Opinie i postawy Polaków wobec relokacji nielegalnych imigrantów na terytorium Rzeczypospolitej, [in:] Migracja i uchodźstwo wyzwaniem dla bezpieczeństwa $i$ wspótpracy międzynarodowej w XXI wieku, ed. B. Molo, Kraków 2016, p. 121-140.

12 N. Krzyżanowska, M. Krzyżanowski, Crisis and migration in Poland: discursive shifts, anti-pluralism and the politicisation of exclusion, "Sociology", 2018, vol. 52 (3), p. 616.

${ }_{13}$ R. Podgórzańska, The issue of securitization of the refugee. Problem in the Polish political debate, "Polish Political Science Yearbook", 2019, vol. 48 (1), p. 67. 


\section{The reasons for the deterioration of the EU - Belarus relations}

The crisis on the border between Poland and Belarus began in 2021 and the events were simultaneously the security problem on the border between Belarus and the European Union. There was a sudden influx of immigrants appearing on the border who came from distant locations in Asia and Africa, in particular, from Iraq and Kurdistan. What the immigrants wanted to achieve was the transfer via Belarus to the European Union. The massive problem of the great number of immigrants forcing the border between Belarus and the EU took place not only on the borders between Belarus and Poland, but on the borders between Belarus and Lithuania and Belarus and Latvia as well.

The migration crisis was not the first deteriorating factor in the relations between the EU member states and Belarus, as the deterioration of the relations between the European Union and Belarus was initiated in 2020, in which time, the presidential election in Belarus was claimed by the EU member states as being non-democratic and not in concord with democratic standards of elections. Not one of the European authorities acclaimed Alexander Lukashenko as the president of Belarus.

The relations between the authorities of the EU states and Belarus deteriorated further due to the event on $23^{\text {rd }}$ May, 2021 when the Ryanair Flight scheduled from Athens to Vilnius was illegally diverted by the Belarusian government to Belarus - to Minsk National Airport - whereupon two activists of the Belarusian opposition - Sofia Sapiega and Roman Protasevich were arrested by Belarusian authorities. A Belarusian fighter jet escorted the passenger plane to Minsk and there was the assumption of a bomb threat. The rest of the passengers (except for the two Belarusian activists) departed from Minsk to Vilnius, and, finally, the regularly - scheduled international passenger flight reached its destination more than eight hours behind schedule. The event was condemned by the North Atlantic Treaty Organisation, the European Union and the United States. Furthermore, the European Union Aviation Safety Agency introduced a directive that halted European airlines from flying over the territory of Belarusian airspace ${ }^{14}$. The majority of international authorities denounced the act and classified it as an act of air piracy and an example of the state terrorism, as well as a violation of international law (among others, the act the Chicago Convention on International Civil Aviation).

\footnotetext{
${ }^{14}$ Safety Directive: SD - 2021-02 by European Union Aviation Safety Agency.
} 


\section{The migration crisis on the border between Belarus and Poland}

The crisis was launched in the summer of 2021, when Alexander Lukashenko started to threaten the European Union with the possibility that there will be an stoppable "flood" from Belarus into the EU of armed immigrants, drug smugglers and human traffickers. It turned out that the authorities of Belarus and tourist enterprises controlled by the Belarusian state began to organize numerous tours from the Middle East to Belarus. The "tourists" were given Belarusian visas, and travelled by plane to Belarus. The aim of most of the 'tourists' was to get to Germany and the Western part of Europe and claim asylum.

The would-be immigrants were given advice how to cross the border into the European Union and were given tips of what to say in case of being found by the border guards on the territory of the EU - either in Poland or in Latvia or in Lithuania. The border was not trespassed only in a peaceful way. Some of the immigrants were instructed and provided with tools to cut border fences and in such a way enter the territory of the European Union. Poland and other member states of the European Union did not agree to their admission into the territory of the EU. Instead the Polish government and EU governments wanted to send humanitarian aid to the deluded 'tourists', but Belarus refused $i t^{15}$. Latvia, Lithuania and Poland classified the situation as an example of a hybrid war that was artificially launched by Belarus and orchestrated by Russia against the European Union.

\section{The legal framework for the state of emergency in the Polish law}

The Constitution of the Republic of Poland as the main source of law in the Republic of Poland formed the legal framework for states of emergency in the 11 th Chapter ${ }^{16}$. The states of emergency could be declared only in the situations of danger when casual constitutional measures were insufficient. Apart from the state of emergency, the lawmaker gave the possibility to impose in Poland, martial law and the state of a natural disaster. The state of emergency could be put in place only on the basis of a particular law (as a decree) that ought to be publicly presented. The rules of the authorities and the scope in which freedom and human rights and the rights of the citizens were restricted in times

15 The website of the Ministry of Foreign Affairs, http://www.gov.pl/dyplomacja, "Polska oferuje pomoc humanitarną imigrantom przebywającym na terytorium Białorusi", access 12.12.2021.

${ }_{16}$ Journal of Laws from $1997 \mathrm{nr}$ 78, pos. 483, The Constitution of the Republic of Poland from 1997, p. 50-52. 
of selected states of emergency must be specified in the law. The particular law must also determine the basis, the scope and the procedures established to compensate the losses caused by the restrictions present in times of the state of emergency. Furthermore, the law must depict the means in which financial support in terms of the states of emergency would be introduced. In addition, the activities established by the government concerning the state of emergency ought to be corresponding with the exact evaluation of a dangerous state. What is more, the undertaken measures should lead to the restoration of a normal functioning of the state.

There are special restrictions concerning the change of law in times of the state of emergency in relation to the Constitution, the Electoral Code ${ }^{17}$ and the regulations for the elections to the municipalities and for the presidential elections. Moreover, the law on the state of emergency cannot be changed, only rescinded ${ }^{18}$.

The decree of the President of Poland on the imposition of the state of emergency

The decree of the President of the Republic of Poland Andrzej Duda from 2nd September, 2021 which was countersigned by the Prime Minister - Mateusz Morawiecki imposed the state of emergency on some of the territory of Poland - on some areas of the Voivodeship of Podlaskie and the Voivodeship of Lubelskie. The state of emergency was introduced on the basis of the Constitution of the Republic of Poland (2nd April, 1997) and the law on the state of emergency (21st June, 2002) ${ }^{19}$. The explanation for the imposition of the state of emergency was the distinctive and real danger to the security of the citizens of the Republic of Poland and real danger to public order. It was explicitly stated that the state of emergency was the implication of the situation on the state border between Belarus and Poland. The initial period for the imposition of the state of emergency was 30 days $^{20}$.

17 Journal of Laws from $2011 \mathrm{nr} 21$, pos. 112, Electoral Code.

18 Journal of Laws from $1997 \mathrm{nr}$ 78, pos. 483, The Constitution of the Republic of Poland from 1997, p. 50-52.

${ }_{19}$ Journal of Laws from 2021 pos. 1612, "Rozporządzenie Prezydenta Rzeczypospolitej Polskiej z dnia 2 września 2021 r. w sprawie wprowadzenia stanu wyjątkowego na obszarze części województwa podlaskiego oraz części województwa lubelskiego".

${ }^{20}$ Ibidem. 
The decree of the President of the Republic of Poland presented the particular restrictions of freedom and human rights in the period of the state of emergency on the territory where the state of emergency was introduced:

- the suspension of the right to organise and participate in assemblies (and therefore - the suspension of some rights specified in the law of assemblies from 24th July, 2015;

- the suspension of the right to organise and participate on the territory of the state of emergency in mass events in the comprehension of the law of the security of the mass events (20th March, 2009) and the suspension of the cultural activities which were not classified as mass events;

- the obligation to have personal ID or another document (people above 18 who were allowed to be present in public places on the territory of the state of emergency); those who were under 18 - were obliged to have school IDs with themselves at all times;

- the ban to be present in selected times in particular places, in particular, buildings located on the territory of the state of emergency;

- the ban to take pictures and make films of the selected places, buildings or areas which are located on the territory of the state of emergency;

- the ban to possess firearms, ammunition or explosives or any other type of guns by the imposition of the ban to possess them on the territory of the state of emergency;

- the restriction of the access for public information concerning the activities on the territory of the state of emergency in the context of the protection of the state border and the prevention of illegal migration ${ }^{21}$. Still, the rules operating in the case of war concerning the obligation of the service in the militarised units were not applicable ${ }^{22}$.

The decree of the Council of Ministers from the $2^{\text {nd }}$ September, 2021 concerning the restrictions of freedom and rights due to the introduction of the state of emergency

On the same day as the presidential decree was issued, an additional law concerning the state of emergency was issued by the Council of Ministers ${ }^{23}$. The decree concerned the restrictions of freedom and rights established because

21 Ibidem.

22 Journal of Laws from 2021, pos. 372, “Ustawa z dnia 21 listopada 1967 r. o powszechnym obowiązku obrony Rzeczypospolitej Polskiej”.

23 Journal of Laws from 2021, pos. 1613, "Rozporządzenie Rady Ministrów z dnia 2 września 2021 r. w sprawie ograniczeń wolności i praw w związku z wprowadzeniem stanu wyjątkowego”. 
of the imposition of the state of emergency. The decree defined the scope of the restrictions of some freedoms and rights:

- the suspension of the right to organise mass assemblies;

- the suspension of the right to organise mass cultural events;

- the obligation to possess ID (if adults) or a student ID (if under 18);

- the ban to be present on the assigned territory of the state of emergency;

- the ban to take pictures and make movies of the appearance or other features, buildings or areas which formed border infrastructure of the state;

- the restriction of the right to have access for public information concerning the activities on the territory of the state of emergency ${ }^{24}$.

There were some exceptions in the act for those who:

- on the day of the imposition of the state of emergency had permanent residence on the area of the state of emergency;

- provided services for the public administration who did public duties in the area of the state of emergency;

- were present on the area of the state of emergency because of appointment in the public office operating on the restricted area;

- worked permanently in the restricted area or ran businesses there;

- owned properties which were located on the area of restriction and their presence was connected with the act of living;

- permanently ran a farm on the restricted area;

- were students (kindergarten, school) or people with disabilities (services for people with special needs) in the restricted area;

- took care of a close person present in the restricted area;

- were people practicing their religious observances or participating in baptisms or wedding ceremonies in the restricted area $^{25}$.

The extension of the state of emergency and the amendment of the law of the protection of the national border

The state of emergency was extended because of the sustained danger on the Polish - Belarusian border. The period of extension was sixty days ${ }^{26}$. After the end of the state of emergency of some of the voivodeship of Lubelskie and

${ }^{24}$ Ibidem.

${ }^{25}$ Ibidem.

${ }^{26}$ Journal of Laws from 2021, pos. 1788, "Rozporządzenie Prezydenta Rzeczypospolitej Polskiej w sprawie przedłużenia stanu wyjątkowego wprowadzonego na obszarze części województwa podlaskiego oraz części województwa lubelskiego". 
Podlaskie, the amended law of the protection of a national border was initiated ${ }^{27}$. The changes of the law imposed a similar set of restrictions that were introduced with the state of emergency ${ }^{28}$. Furthermore, the authorities of Poland decided to build a fence on the border between Poland and Belarus ${ }^{29}$.

The amendment of the law on the protection of the state border was passed on the 17th November, 2021, by the Polish Parliament and was finally signed into law by the President of the Republic of Poland on 30th November, $2021^{30}$. The representatives of the Ministry of Home Affairs and Administration justified the necessity of the changes because of the situation on the border. There was no possibility to extend the state of emergency (it was already extended once for sixty days). The amendment of the law on the protection of the state border was a substitution for the state of emergency as it caused the prolongation of the legal solutions as if the state of emergency practically did not end in some parts of the territory of two voivodeships in the Republic of Poland ${ }^{31}$.

The law on the protection of the state border improved the position of the Border Guards. In particular, the law enabled the presence of journalists in the restricted area, albeit with official approval and in an organized body. Moreover, the regulations made it possible to be present in the area of the territory which used to be the area of banned presence. The actions underwent by the Polish government were due to the prediction that the crisis might expand. The amendment of the law engendered legal change throughout the entire external border of the Schengen area - on the borders with Belarus, Ukraine and Russia (Kaliningrad region).

The Ministry of Home Office and Administration of the Republic of Poland claimed every public services were prepared to help those who needed some help within the territory of the Republic of Poland. The notion of first aid being given to immigrants appearing in Poland was one of the issues raised by the opposition in the Polish Parliament on the debate on the amendment of law. None of the humanitarian aid offered by Poland, however, was accepted by Belarus ${ }^{32}$.

\footnotetext{
${ }^{27}$ Journal of Laws from 1990, nr 78 pos. 461, “Ustawa o ochronie granicy państwowej”.

${ }^{28}$ Ibidem.

${ }^{29}$ Journal of Laws from 2021, pos. 1992, “Ustawa o budowie zabezpieczenia granicy państwowej".

${ }^{30}$ The website of the Polish government, https://www.gov.pl, "Prezydent podpisał nowelizację ustawy o obronie granicy państwowej i niektórych innych ustaw", access 12.12.2021.

31 The website of Rzeczpospolita, https://www.rp. pl/, "Stan wyjątkowy po stanie wyjątkowym", access 12.12.2021.

${ }^{32}$ The website of the Polish government, https://www.gov.pl, "Polska oferuje pomoc humanitarną imigrantom przebywającym na terytorium Białorusi”, access 12.12.2021.
} 
The amendment of the law on the protection of the state border was justified by the migration pressure on the Eastern border of the Republic of Poland. Furthermore, on the Polish - Belarusian border there were some dangerous incidents involving guns and involving Belarusian authorities.

The final remarks on the implications of the migration crisis on Polish Belarusian border

The line of the political conflict in the political arena of the Republic of Poland concerning the migration crisis was not as clear as it was in other parliamentary debates. The discussion on the imposition was full, with strong arguments put forward by both sides - the government and the opposition. One of the key aspects that differentiated the parties was the attitude of the presence of journalists on the border of Poland and Belarus. The second clash of the parliamentary debate was connected with the primary aspect - the understanding of the whole problem and the aspects of human rights. The government claimed that the people who wished to enter the border between Belarus and Poland were economic immigrants, whereas some MPs of the Polish Parliament (mainly from the left-wing side) claimed they were refugees and as such, their assistance was an obligation by Poland, under international law.

The authorities of Poland also claimed that the activities of Belarus broke international law and were immoral in the context of human rights. In addition, the government claimed that Belarus was responsible for tragedies of those who either died or suffered from severe illness due to the fact that there was no entry into the territory of Poland. The activities undertaken by Belarus were also seen as blackmail against the European Union - an attempt to force the EU to either pay Belarus to keep out would-be immigrants to the EU, or to lift the sanctions introduced by the EU against Belarus after the presidential elections and the act of air piracy..

The reaction of the Polish government was strong with one goal - protect the border. The authorities of Poland claimed there was no comparison between the migration crisis on 2015 and 2016 and the artificial wave of migration created by Alexander Lukashenko on the border with Poland, and thereby - with the European Union. Still, there was one constant aspect of the stance of Poland towards such waves of migration - Poland was ready to help people in the places they came from - in the states of their origin, while Poland rejected an open door policy ${ }^{33}$.

33 A. Potyrała, Poland towards the migration crisis of 2015-2016, „Przeglacd Politologiczny”, 2016 (2), p. 75. 
One may denote that the European Union still lacked a unified immigration policy, similarly as in 2015. Still, none of the authorities of the EU claimed that the solution to the problem would be a quota system after letting the immigrants break the border and enter Poland and simultaneously - the Schengen zone of the European Union. However, many of the EU member states took a national perspective towards the problem, not a EU-wide perspective.

One of the actions taken by the institutions of the EU was to impose more sanctions against Belarus. Herein, the President of the European Commission, Ursula von der Leyen claimed the instrumentalisation of immigrants for the political purposed by Belarus was unacceptable. The President of the EU Commission stated outright that pressuring the European Union with the use of immigrants was a cynical action that could not be approved. Furthermore, the Commission of the EU said that they wanted to cooperate with the United Nations and their specialised agencies to prevent a humanitarian crisis and ensure that the would-be immigrants, lured by false promises by Belarus, would be safely returned to their countries of origin with the support of their national authorities ${ }^{34}$.

\section{The conclusions}

The migration problem in Poland in 2021 and the crisis on the border displayed the problem of exact classification between asylum-seekers and economic immigrants. There was no migration policy established in Poland ${ }^{35}$. It was widely understood, mainly by the right wing parties, that the massive wave of migration - both in 2015 and in 2021, consisted of a great number of people who were economic immigrants, not asylum-seekers ${ }^{36}$. However, the authorities of Poland of both political persuasions wished to help those who appeared on the territory of the Republic of Poland and to give humanitarian aid for the bona fide refugees struggling to enter the territory of the European Union ${ }^{37}$. Never-

${ }^{34}$ The website of the European Commission, http:// www.ec.europa.eu, "European Commission - the statement from the 8th November, 2021".

${ }_{35}$ G. Tutak, Polityka migracyjna Polski wobec europejskiego kryzysu migracyjnego, „Świat Idei i Polityki", 2018, vol. 17, p. 473-48; M. Stolarczyk, Stanowisko Polski wobec kryzysu migracyjno - uchodźczego Unii Europejskiej, "Krakowskie Studia Międzynarodowe", 2017, vol. XIV, nr 2, p. 30-41; A. Adamczyk, Kryzys migracyjny w Europie a polska polityka migracyjna, „Studia Migracyjne - Przegląd Polonijny", 2017, Vol. 1 (163), p. 307-331.

${ }^{36}$ J. Balicki, Zjednoczona Prawica $w$ Polsce wobec kryzysu migracyjnego w Europie. Perspektywa polityczno - etyczna, "Wschodni Rocznik Humanistyczny", 2019, nr 4, p. 63-82.

37 See: A. Bałamut, Polska wobec kryzysu imigracyjnego w Unii Europejskiej, [in:] Migracja $i$ uchodźstwo wyzwaniem dla bezpieczeństwa $i$ wspótpracy międzynarodowej w XXI wieku, ed. B. Molo, Kraków 2016, p. 103-120. 
theless, there were no certain criteria for distinguishing economic immigrants from other types of immigrants that would be accepted widely by the political parties acting within the political arena of Poland ${ }^{38}$. The authorities claimed that the imposition of the state of emergency helped the state to organise an effective counter to the migration crisis that helped in protecting both the borders of Belarus and Poland and Belarus and the European Union.

\section{Bibliography}

\section{Sources of law}

- Journal of Laws from 1990, nr 78 pos. 461, "Ustawa o ochronie granicy państwowej”.

- Journal of Laws from $1997 \mathrm{nr}$ 78, pos. 483, The Constitution of the Republic of Poland from 1997.

- Journal of Laws from $2011 \mathrm{nr} 21$, pos. 112, Electoral Code.

- Journal of Laws from 2021, pos. 372, "Ustawa z dnia 21 listopada 1967 r. o powszechnym obowiązku obrony Rzeczypospolitej Polskiej”.

- Journal of Laws from 2021 pos. 1612, "Rozporządzenie Prezydenta Rzeczypospolitej Polskiej z dnia 2 września $2021 \mathrm{r}$. w sprawie wprowadzenia stanu wyjątkowego na obszarze części województwa podlaskiego oraz części województwa lubelskiego".

- Journal of Laws from 2021, pos. 1613, "Rozporządzenie Rady Ministrów z dnia 2 września $2021 \mathrm{r}$. w sprawie ograniczeń wolności i praw w związku z wprowadzeniem stanu wyjątkowego".

- Journal of Laws from 2021, pos. 1788, "Rozporządzenie Prezydenta Rzeczypospolitej Polskiej w sprawie przedłużenia stanu wyjątkowego wprowadzonego na obszarze części województw podlaskiego oraz części województwa lubelskiego".

- Journal of Laws from 2021, pos. 1992, "Ustawa o budowie zabezpieczenia granicy państwowej".

- Safety Directive: SD - 2021-02 by European Union Aviation Safety Agency.

\section{Literature}

- Adamczyk A., Kryzys migracyjny w Europie a polska polityka migracyjna, „Studia Migracyjne - Przegląd Polonijny", 2017, Vol. 1 (163).

- Adamczyk N., Czy przyjmować uchodźców? Opinie i postawy Polaków wobec relokacji nielegalnych imigrantów na terytorium Rzeczypospolitej, [in:] Migracja i uchodźstwo wyzwaniem dla bezpieczeństwa $i$ wspótpracy międzynarodowej w XXI wieku, ed. B. Molo, Kraków 2016.

- Balicki J., Zjednoczona Prawica w Polsce wobec kryzysu migracyjnego w Europie. Perspektywa polityczno - etyczna, "Wschodni Rocznik Humanistyczny", 2019, nr 4.

${ }^{38}$ Compare: B. Cieślińska, M. Dziekońska, The ideal and the real dimensions of the European migration crisis. The Polish perspective, "Social Sciences" 2019, nr 8 (314), p. 1. 
- Bałamut A., Polska wobec kryzysu imigracyjnego w Unii Europejskiej, [in:] Migracja $i$ uchodźstwo wyzwaniem dla bezpieczeństwa $i$ wspótpracy międzynarodowej $w$ XXI wieku, ed. B. Molo, Kraków 2016.

- Cieślińska B., Dziekońska M., The ideal and the real dimensions of the European migration crisis. The Polish perspective, "Social Sciences" 2019, nr 8 (314).

- Chojan A., Olszewski P. , Kryzys migracyjny jako problem globalny. Konsekwencje dla polityki zagranicznej i bezpieczeństwa Unii Europejskiej, "Roczniki Nauk Społecznych", 2018, vol. 10 (46), nr 1.

- Dahl M., Dziudziuk A., Państwa Unii Europejskiej wobec kryzysu imigracyjnego z 2015 roku, "Unia Europejska”, 2017 (244), nr 3.

- Dahl M., Europejski kryzys imigracyjny z 2015 roku i jego wptyw na prowadzona przez Polske w latach 2015-2018 politykę zagraniczną, "Myśl Ekonomiczna i Polityczna", 2019, nr 2 (65).

- Krzyżanowska N., Krzyżanowski M., Crisis and migration in Poland: discursive shifts, anti-pluralism and the politicisation of exclusion, "Sociology", 2018, vol. 52 (3).

- Lasoń M., Stanowisko polskich partii politycznych wobec problemu uchodźstwa $i$ imigracji w drugiej dekadzie XXI wieku, [in:] Migracja i uchodźstwo wyzwaniem dla bezpieczeństwa $i$ wspótpracy międzynarodowej w XXI wieku, ed. B. Molo, Kraków 2016.

- Pacek M., Polish migration Policy in the context of the migration crisis, "Studia Europejskie", 2020, nr 2.

- Piłat A., Potkońska D., Local responses to the refugee crisis in Poland. Reception and integration, Warsaw 2017.

- Podgórzańska R., The issue of securitization of the refugee. Problem in the Polish political debate, "Polish Political Science Yearbook", 2019, vol. 48 (1).

- Potyrała A., Poland towards the migration crisis of 2015-2016, „Przegląd Politologiczny", 2016 (2).

- Rajca L., The evolution of the approach to the integration of immigrants in Poland, "Studia Europejskie", 2021, vol. 3.

- Starzyk A., Kryzys migracyjny a sytuacja partii prawicowych w Grupie Wyszehradzkiej w 2015 roku, "Wrocławskie Studia Politologiczne”, 2016, nr 20.

- Stolarczyk M., Stanowisko Polski wobec kryzysu migracyjno - uchodźczego Unii Europejskiej, "Krakowskie Studia Międzynarodowe", 2017, vol. XIV, nr 2.

- Szymańska J., Strategia Unii Europejskiej wobec kryzysu migracyjnego: priorytety, bariery, efekty, "Studia Biura Analiz Sejmowych", 201, nr 3 (51).

- Tutak G., Polityka migracyjna Polski wobec europejskiego kryzysu migracyjnego, „Świat Idei i Polityki", 2018, vol. 17.

- Zdanowicz M., Poland's stance on the refugee and migration crisis in the European Union, "Białostockie Studia Prawnicze”, 2021, vol. 26, nr 1.

\section{The Internet sources}

- The website of Rzeczpospolita, https://www.rp. pl/, "Stan wyjątkowy po stanie wyjątkowym". 
- The website of the European Commission, http:// www.ec.europa.eu, "European Commission - the statement from the 8th November, 2021".

- The website of the Ministry of Foreign Affairs, http://www.gov.pl/dyplomacja, "Polska oferuje pomoc humanitarną imigrantom przebywającym na terytorium Białorusi”.

- The website of the portal YouTube, http://www.youtube.com, "Wystąpienie Jarosława Kaczyńskiego w Sejmie Rzeczypospolitej Polskiej dnia 16 września 2015 r.”

- The website of the Polish government, https://www.gov.pl, "Polska oferuje pomoc humanitarną imigrantom przebywającym na terytorium Białorusi".

- The website of the Polish government, https://www.gov.pl, "Prezydent podpisał nowelizację ustawy o obronie granicy państwowej i niektórych innych ustaw".

Summary: The imposition of the state of emergency of 2021 on some parts of the territory of Poland was connected with the crisis on the border between Poland and Belarus. There were numerous groups of immigrants who wished to cross the border of the Schengen zone - both peacefully and violently. The reaction of the authorities of the Republic of Poland was strong there was the necessity to protect the border. In order to achieve the goal, a decision to build a barrier on the border was made. The system analysis and the analysis of the decision-making process proved that the level of the political conflict in Poland is on a stable high level that is not minimalised even in the case of external danger.

Key words: the state of emergency, order crisis, migration crisis; a political conflict;

Wprowadzenie stanu wyjątkowego na części terytorium Polski w 2021 r. w związku kryzysem migracyjnym na granicy z Białorusią

Streszczenie: Wprowadzenie stanu wyjątkowego na części terytorium Polski było związane z kryzysem na granicy Polski z Białorusią. Kryzys był związany z licznymi grupami migrantów, które chciałby przedostać się do strefy Schengen z Białorusi. Reakcja władz RP była związana z koniecznością obrony granicy Polski, która była zarazem granicą Unii Europejskiej. W celu skutecznej ochrony granicy podjęto decyzję o budowie zapory oddzielającej Polskę i Białoruś. Analiza systemowa oraz zbadanie procesu decyzyjnego w sprawie przedmiotowej materii pozwoliła na konstatację, że poziom sporu politycznego w Polsce jest na tak wysokim poziomie, który nie jest minimalizowany nawet w sytuacji zagrożenia zewnętrznego.

Słowa - klucze: stan wyjątkowy, kryzys graniczny, kryzys migracyjny, konflikt polityczny; 